\title{
Izazovi produljenja ljudskoga života na razmeđu poboljšanja $i$ agonije
}

\author{
ODILON-GBÈNOUKPO SINGBO* - \\ Terezija GLOŽINIĆ ${ }^{* *}$ - Anto ČARTOLOVNI*** \\ • https://doi.org/10.31823/d.28.3.3 • \\ UDK: $614.2^{*} 179$ • Izvorni znanstveni rad \\ Primljeno: 15. studenoga 2019. • Prihvaćeno: 8. rujna 2020.
}

${ }^{*}$ Dr. sc. Odilon-

Gbènoukpo Singbo,

Hrvatsko katoličko sveučilište, Ilica 242, 10000 Zagreb, Hrvatska, odilonsing@gmail.com

** Terezija Gložinić, univ. bacc. med. techn.,

Hrvatsko katoličko sveučilište, Ilica 242, 10000 Zagreb, Hrvatska, tglozinic@unicath.hr

*** Doc. dr. sc.

Anto Čartolovni, Hrvatsko katoličko sveučilište, Ilica 242 , 10000 Zagreb, Hrvatska, anto.cartolovni@ unicath.hr

Sažetak: Ovaj rad nastoji prikazati dva načina produljenja ljudskoga života. S jedne strane nalazi se distanazija, tj. terapijska upornost oko produženja života teškoga bolesnika, a $s$ druge strane transhumanizam kao filozofski pravac koji u svojoj srži teži bezgraničnom produžavanju ljudskoga života $s$ temeljnom željom za eliminiranjem bolesti, starenja i smrti. Povezujući ih s medicinskom praksom, rad pokazuje implikacije u klinickoj praksi te nastoji upozoriti na etička i antropološka pitanja o produžavanju života.

Ključne riječi: distanazija, transhumanizam, medicinska tehnologija, produžavanje života, bolest, smrt, besmrtnost, bioetika.

\section{Uvod}

Znanstvena otkrića s područja tehnologije u velikoj mjeri utječu na razvoj medicinske djelatnosti. Retrospektivni pogled u povijest pomaže utvrditi da su se uz pomoć medicinske tehnologije uspjele iskorijeniti neke zarazne bolesti, ali i uspješno liječiti kronične nezarazne bolesti od kojih su ljudi prije redovito umirali. Sve to doprinijelo je značajnom produžetku životnoga vijeka te samo po sebi ne podrazumijeva ništa loše, zapravo, suprotno, borba protiv bolesti doprinijela je i kvaliteti ljudskoga života. No ono što se najviše promijenilo jest čovjekov pogled na smrt i umiranje. Smrt postaje nešto što se želi izbjeći ili barem malo odgoditi, što se, zapravo, i uspijeva uz pomoć medicinskih tehnologija. Upotreba tih tehnologija sa sobom nosi i razne 
etički upitne procese i postupke. Stoga je potrebno nanovo isticati filozofsko-religijski pogled na ljudski život kroz razne filozofske pravce koji nude različite smjernice i vrijednosti za život. Zatim analizirati i redefinirati ciljeve medicinske djelatnosti, svjesni da razvoj medicine utječe na način produženja čovjekova životnoga vijeka i način na koji on gleda na trenutke patnje i umiranja. Dva se pristupa čovjeku danas nameću kao nove paradigme koje ne idu uvijek u skladu s dostojanstvom ljudske osobe - bilo da je osoba zdrava bilo da se nalazi u teškim trenutcima bolesti. Riječ je o distanaziji i transhumanizmu. Cilj je ovoga rada u trenutačnoj fazi znanstvenotehničko-medicinskoga razvoja raskrinkati antropološko-etičko-kliničke implikacije jedne i druge paradigme.

\section{Kratke crte filozofsko-religijskoga pogleda na život}

Povijest filozofije pokazuje nam da se filozofska misao o ljudskom životu i smrti mijenjala i razvijala te se na to pitanje ne može naći jedinstven odgovor. Neki će smatrati kako se punina života nalazi u raznim užitcima (hedonizam), neki će pak obezvrjeđivati život (nihilizam). U grčkoj filozofiji veliku ulogu u razumijevanju života igra odnos s božanskim. To je posebice vidljivo u grčkoj mitologiji koja želi naglasiti moć i veličinu bogova kao bića iznad čovjeka, bića koja čovjeku mogu darovati sve, ali i oduzeti sve, pa čak i dati mu besmrtnost. U tom smislu važno je spomenuti Platona koji vezano za besmrtnost u svojoj filozofiji spominje moralnu obvezu čovjeka prema budućnosti da se besmrtnost vrste postiže rađanjem djece. ${ }^{1}$ Uz grčku filozofiju vežu se i cinici, stoici i Kirenska škola. Cinici smatraju da se u životu ne treba brinuti oko prolaznih stvari kao što su bogatstvo, politička moć i dobro zdravlje. ${ }^{2}$ Među stoicima važno je istaknuti Epikura koji tvrdi kako je smrt najgroznije zlo koje se ipak ne tiče nas koji smo živi jer »dokle god mi jesmo, nema smrti. A kad smrt dođe, onda više nema nas $\ll^{3}$. Kirenska škola promiče hedonizam kao životnu utjehu. ${ }^{4}$ Njihova se filozofija temelji na postavci da se dobro ostvaruje samo kroz stanje naslade koje dolazi iz zadovoljene želje. Zanimljiva je činjenica da je posljednji predstavnik Kirenske škole Hegezija ostavio pozitivan stav hedonizma i priklonio se pesimizmu te došao do svojevrsne filozofije životnoga apsurda i tako pokrenuo filozofski pravac suprotan hedonizmu. ${ }^{5}$ Slijedom toga, možemo

${ }^{1}$ Usp. S. JONES, Jezik gena, Zagreb, 2007., 116.

${ }^{2}$ Usp. J. GAARDER, Sofijin svijet: Roman o povijesti filozofije, Zagreb, 1997., 113-117.

${ }^{3}$ EPIKUR, Osnovne misli: Poslanica Herodotu; Poslanica Menekeju, M. N. Đurić (ur.), Beograd, 1959., 124b-7.

${ }^{4}$ Usp. Antička filozofija, u: Proleksis enciklopedija, 2012. Dostupno na: http://proleksis.lzmk.hr/ 55904/ (15.3. 2019.).

${ }^{5}$ Usp. Hegezija, u: Hrvatska enciklopedija. Dostupno na: http://www.enciklopedija.hr/natuknica. aspx?id=24749 (15.3. 2019.). 
zaključiti kako s jedne strane filozofija nudi jednu krajnost - hedonizam, dok s druge strane, Hegezijinim stopama, filozofija nudi drugu krajnost koja se naziva nihilizam (lat. nihil - 'ništa'). Prema nihilizmu, čovjekova je egzistencija bez cilja i svrhe. Nihilizam se najčešće povezuje s Friedrichom Nietzscheom. On negira Boga i ujedno smatra da je $u$ »Bogu objavljeno neprijateljstvo prema životu, prema prirodi, prema volji za životom. $\ll^{6}$ Za njega je »volja za životom osnovni kriterij, ali u prirodnom stanju ona je i volja za moći $\ll^{7}$. U volji za moći Nietzsche je vidio temelj novoga čovjeka. ${ }^{8}$ Ta filozofija novoga čovjeka, odnosno ideja nadčovjeka, poslužila je kasnije nacističkoj Njemačkoj u provedbi eugenike. Valja spomenuti i filozofiju egzistencijalizma kao »suvremeni filozofski smjer čija je osnovna postavka da na svijet, život i čovjeka treba gledati iz perspektive individualnoga Ja, a ne nikakvih vječnih i općenito vrijednih istina « ${ }^{9}$. Pri tome stavljajući naglasak na slobodu pojedinca.

Dok ti filozofski pravci gledaju na život kao prolaznu zbilju, temelj kršćanskoga pogleda na život i čovjeka nalazi se u Svetom pismu čija se okosnica nalazi u neprolaznome. U Knjizi Postanka čovjeku je život dan kao dar, da ga čuva u suradničkoj poslušnosti Bogu Stvoritelju. Površno rečeno, iskustvo jedenja sa zabranjenoga stabla dovelo je čovjeka do iskustva smrti kao lutanja od Boga: »Tada Jahve, Bog, učini te iz zemlje nikoše svakovrsna stabla - pogledu zamamljiva a dobra za hranu - i stablo života, nasred vrta, i stablo spoznaje dobra i zla ( ... Jahve, Bog, zapovjedi čovjeku: 'Sa svakoga stabla u vrtu slobodno jedi, ali sa stabla spoznaje dobra i zla da nisi jeo! U onaj dan u koji s njega okusiš, zacijelo ćeš umrijeti!' « (Post 2, 9.16-17) Jedenje plodova sa stabla spoznaje dobra i zla donosi smrt, dok jedenje plodova sa stabla života donosi život, tj. besmrtnost. ${ }^{10}$ Svoj prvi grijeh čovjek čini neodgovorno iskorištavajući svoju slobodu upravo tako da je jeo plodove sa stabla spoznaje dobra i zla i tako ugrožava svoj život. Bitno je istaknuti da nije čovjeku ovdje zabranjeno jesti plodove od svih drugih stabala, jer jasno je istaknuto: »Sa svakoga stabla u vrtu slobodno jedi «. No jedino zabranjeno stablo zauzelo je - po zmijinoj lukavosti - cijelu čovjekovu pozornost do te mjere da je sekundarna zabrana (ali sa stabla spoznaje dobra i zla da nisi jeo!) zasjenila prvotnu i širu dozvolu (Sa svakoga stabla u vrtu slobodno jedi). U Božjem je dakle naumu da čovjeku daje neizmjeran

\footnotetext{
${ }^{6}$ F. NIETZSCHE, Antikrist: prokleto kršćanstvo, Zagreb, 1999., 18.

${ }^{7}$ Friedrich Nietzsche, u: Hrvatska enciklopedija. Dostupno na: http://www.enciklopedija.hr/natuknica.aspx?id=43734 (15.3. 2019.).

${ }^{8}$ Isto.

${ }^{9}$ A. KUSIĆ, Dva aspekta suvremenog egzistencijalizma, u: Crkva u svijetu 11(1976.)2, 123-131., ovdje 123.

${ }^{10}$ Usp. C. TOMIĆ, Simbolika stabla, u: Obnovljeni život 42(1987.)5, 428-432., ovdje 430.
} 
prostor života i uživanja u njegovim blagodatima, a ne da ga sužanjski ograničava. Nadalje, u knjizi Ponovljenoga zakona Bog čovjeku ponovno daje mogućnosti izbora: »Gledaj! Danas preda te stavljam: život i sreću, smrt i nesreću « (Pnz 30, 15). Upozorava ga da jedino slušanjem Gospodnjih zapovijedi i hodeći njegovim putovima može osigurati život. Zapravo, daje mu upute i sugerira: $\gg$ Uzimam danas za svjedoke protiv vas nebo i zemlju da pred vas stavljam: život i smrt, blagoslov i prokletstvo. Život, dakle, biraj... «(Pnz 30, 19) Život je dakle znak poslušnosti Bogu ispravne slobode. Upute su to za čovjeka da uvijek štiti život, gleda na život kao na dar i na blagoslov. Bog zapravo potiče na izbor života.

Stoga je otajstvo Božjega utjelovljenja događaj koji svjedoči o ljepoti i vrijednosti života i o ponovnom pozivu na Božje upute iz Ponovljenoga zakona: da život biramo. U Evanđelju po Ivanu Isus to jasno ističe ovim riječima: »Ja dođoh da život imaju, u izobilju da ga imaju « (Iv 10, 10). Teološka implikacija tih riječi sastoji se u tome da život kao biološka zbiljnost nosi otajstvo neprolaznoga, vječnoga. Stoga ne trpi relativistički, redukcionistički pristup. Potvrda toga dolazi iz Isusovih mnogobrojnih čudesnih ozdravljenja koja nisu samo tjelesne naravi nego su duhovni i duhovski događaji (usp. ozdravljenje gubavca - Mk 1, 40-45; ozdravljenje uzetoga - Lk 5, 18-25; ozdravljenje dva slijepca - Mt 9, 27-31 i dr.). To pokazuje da se Bog zauzima za život tamo gdje je život ugrožen, što fizički u obliku bolesti, što duhovno u obliku opsjednutosti. No u Isusovu pristupu fizičko ozdravljenje uvijek uključuje i duhovno spasenje i obrnuto. Samim je Isusovim dolaskom i uskrsnućem čovjeku darovan život vječni. No taj dar života nije stvar fizičke besmrtnosti, već vodi kroz smrt u život u Isusu Kristu raspetom i uskrslom; o čemu svjedoče Pavlove poslanice (usp. 1 Kor 15 i Rim 7).

\section{Biomedicinska profesija u službi života}

Medicina se uvelike razvijala od svojih početaka doprinoseći boljitku ljudskoga života. U klasične ciljeve medicine može se svrstati spašavanje i produljivanje života, poboljšavanje i održavanje kakvoće zdravlja te ublažavanje boli i patnje. Valja istaknuti da njihovo ostvarenje postaje upitno ako nije više u službi dobra čovjeka. Ako govorimo o spašavanju i produljivanju života, treba se pitati znači li što taj cilj danas kada postoje aparati koji će održati život osobe koja bi bez djelovanja toga aparata već bila umrla. $U$ doba genetičkoga inženjeringa i pokušaja interveniranja u ljudski genom radi eliminiranja bolesti i povećanja godina životnoga vijeka, možemo li kao cilj medicine navesti spašavanje i produljivanje života? Drugo, poboljšavanje i održavanje zdravlja također danas predstavlja izazov. Naime »genetsko istraživanje stalno razvija sve sofisticiranije oblike predvidljive medicine, ali što to znači za osobe koje već od djetinjstva znaju za vjerojatnost kasnijeg razvijanja bo- 
lesti srca ili Alzheimerove bolesti? $\ll{ }^{11}$ Uslijed razvoja tehnologije, a posljedično i razvoja medicine, postoji jasna potreba za redefinicijom klasičnih ciljeva medicine. $\mathrm{Na}$ to utječu mnogi izazovi kao što su, prema Pessiniju ${ }^{12}$, znanstveni i tehnološki napredak, uravnoteženje kurativne tendencije, starenje stanovništva, tržište i javna potražnja, kulturni pritisci, medikalizacija života te krajnja i neostvariva težnja medicine u obliku ljudske savršenosti. Kao nove, redefinirane ciljeve medicine Pessini predlaže sljedeće: prvo, prevencija bolesti i patnje te promicanje i održavanje zdravlja. Ovdje stavlja naglasak na važnost javnoga zdravstva jer je bolje spriječiti nego liječiti. Kao drugi cilj navodi ublažavanje boli i patnje, gdje naglašava da je suvremena medicina promašila taj cilj i da je pitanje patnje često pitanje duhovnoga ili filozofskoga obilježja. Slijedom toga, medicina mora »priznati svoje vlastite granice i spoznati da ne može kontrolirati cjelokupan život $\ll^{13}$. Upravo za to je vezano pitanje i distanazije i palijativne skrbi. Kao treći cilj navodi se liječenje i skrb o osobama s izlječivim i neizlječivim bolestima. Ovdje je bitno naglasiti kako medicina ne bi smjela podrazumijevati samo liječenje, bez skrbi. Često dijagnoze neizlječivih bolesti za medicinu predstavljaju kraj jer liječenje više nije moguće te u tim situacijama medicina izuzima upravo skrb, koja je u terminalnim fazama najbitnija. Kao četvrtu smjernicu za cilj Pessini navodi izbjegavanje prerane smrti i traženje mirne smrti. Izbjegavanje prerane smrti ne znači činiti sve u terminalnoj fazi bolesti kada liječenje više nije moguće. To znači da »prvenstvena dužnost medicine i zdravstvenih sustava je pomoći mladima da dočekaju starost i da dostojanstveno žive ostatak života, do posljednjeg časa svojega postojanja $\ll{ }^{14}$. Ovdje se može spomenuti pitanje siromašnih zemalja u kojima vladaju nepravedne politike javnoga zdravstva, nedostupnost resursa i zdravstvene skrbi, pa mnogi ljudi umiru mladi od bolesti koje se u zapadnom svijetu normalno liječe. Medicina treba prestati doživljavati smrt »kao izbježiv biološki slučaj, kao medicinsku pogrešku « ${ }^{15}$. Prihvaćanje smrti kao neizbježnoga dijela čovjekova života doprinijet će sve većoj težnji k mirnoj i dostojanstvenoj smrti i smanjit će broj nepotrebnih postupaka održavanja na životu.

\section{Produžavanje života između dobrobiti i agonije}

\subsection{Paradoks produljenja života}

Kako je jedan od klasičnih ciljeva medicine produljiti život, može se vidjeti da je taj cilj uistinu ostvariv, tj. ostvaruje se. Primjećuje se veliko produljenje prosječnoga

\footnotetext{
${ }^{11}$ L. PESSINI, Distanazija: Do kada produžavati život, Rijeka, 2004. 39.

${ }^{12}$ Isto, 40-46.

${ }^{13}$ Isto, 49.

${ }^{14}$ Isto, 50.

${ }^{15}$ Isto, 51.
} 
životnoga vijeka u posljednjih sto godina, što određeni statistički podatci mogu i potkrijepiti. Naime očekivano trajanje života u SAD-u 1900. godine bilo je 48,3 godina za muškarce i 46,3 godina za žene, a povećalo se 2001. godine na 74,2 za muškarce i 79,9 godina za žene ${ }^{16}$. U SAD-u za muškarce je 2018. godine očekivano trajanje životnoga vijeka 77,8 godina, a za žene 82,3 godine.${ }^{17}$ Manji skok u povećanju očekivanoga trajanja života primjećuje se i u Hrvatskoj. Godine 2000. očekivano trajanje za muškarce bilo je 70,04 , a za žene 77,51 godinu. ${ }^{18}$ Godine 2018. očekivana životna dob za muškarce bila je 73,2 godine, dok je za žene 79,6 godina. ${ }^{19}$ Tomu su doprinijeli već spomenuti napredak tehnologije, medicine (i kurativne, i preventivne, i rehabilitacijske), nove spoznaje o starenju i starosti, prehrani, tzv. zdravom načinu života i zdravstvenom ponašanju općenito, otkriće antibiotika, uvođenje asepse i anestezije, kemoterapije te općeniti razvoj kirurške tehnike. Isto tako tomu svemu prethodio je značajan razvoj biologije, kemije, fizike, nanotehnologije i biotehnologije.

No važno je naglasiti paradoksalnu neravnotežu u dužini životnoga vijeka koja se primjećuje među državama razvijenoga i nerazvijenoga svijeta. Kao primjer možemo navesti Monako kao zemlju s najdužim očekivanim životnim vijekom - 89,4 godina (2018.) i Afganistan kao zemlju s najkraćim očekivanim životnim vijekom - 52,10 godina (2018.). ${ }^{20}$ Dakle razlika u očekivanim životnim vjekovima između te dvije zemlje jest čak 37,3 godine. Možemo si postaviti pitanje koji je razlog tolike neravnoteže. Ako govorimo općenito o starosti i čimbenicima koji utječu na tzv. dobro starenje, mogu se nabrojiti brojni: dobre navike, pravilna i zdrava prehrana, tjelesna aktivnost, redovit san te dostupnost $\mathrm{i}$ učinkovitost zdravstvene zaštite. Zaustavimo se nakratko na zadnjem. Nedostatci te često izostajanje javnih zdravstvenih politika ostavljaju stanovnike nerazvijenih zemalja u situaciji da nemaju izbora. Zdravstveno osiguranje ne postoji, a sredstava za plaćanje zdravstvenih usluga u privatnim, ali i državnim ustanovama nema. Dakle narod je često prepušten raznim narodnim i alternativnim medicinama koje zasigurno ne liječe kao što to može kla-

${ }^{16}$ Usp. F. FUKUYAMA, Kraj čovjeka? Naša poslijeljudska budućnost: Posljedice biotehnološke revolucije, Zagreb, 2003., 78.

${ }^{17}$ CENTRAL INTELLIGENCE AGENCY, The world factbook: United States za 2018., 2019. Dostupno na: https://www.cia.gov/library/publications/the-world-factbook/geos/us.html (19.2. 2019.).

${ }^{18}$ ISTI, The world factbook archives: Croatia za 2000., 2007. Dostupno na: https://www.cia.gov/ library/publications/download/download-2000/index.html (14. 6. 2019.).

${ }^{19}$ ISTI, The world factbook: Croatia za 2018., 2019. Dostupno na: https://www.cia.gov/library/ publications/the-world-factbook/geos/hr.html (14.6. 2019.).

${ }^{20}$ ISTI, The world factbook: Country Comparison: Life expectancy at birth, 2019. Dostupno na: https://www.cia.gov/library/publications/the-world-factbook/fields/355rank.html\#US (19. 2. 2019.). 
sična medicina ili, nažalost, umiru od bolesti koje se u zapadnom svijetu redovito liječe. Važno je spomenuti također i porast očekivanoga životnoga vijeka u tim područjima. Možemo usporediti očekivani životni vijek u afričkoj državi Republici Benin iz 2000. godine te iz 2018. godine. Za stanovnike Benina poraslo je očekivano trajanje života s 50,18 godina na 62,7 godina ${ }^{21} \mathrm{Na}$ osnovu predstavljene statistike može se zaključiti da je jedan od ključnih uzroka neravnoteže životnoga vijeka između razvijenih i nerazvijenih zemalja nedostupnost zdravstvene zaštite u nerazvijenim zemljama i neposjedovanje razvijenih medicinskih tehnologija kojima se uobičajeno koristi zapadni svijet.

\subsection{O SUVREMENIM NAČINIMA PRODUŽIVANJA ŽIVOTA}

Da bi se moglo govoriti o načinima produživanja života, potrebno je ukratko predstaviti suvremene aktualne načine poboljšavanja čovjekova života. Iako poboljšanje možda zvuči kao odrednica ili svojstvo nekoga tehničkoga uređaja ili programske podrške, također se primjenjuje i na čovjeku, čovjekovu životu i životnim uvjetima već niz godina. Neki od takvih sredstava olakšavaju čovjeku život i omogućuju mu lakše funkcioniranje ako ima neki tjelesni nedostatak. Kao primjer mogu se navesti naočale za vid. Iako zvuči banalno, naočale su dio terapeutske tehnologije koja pomaže čovjeku vidjeti bolje i $u$ isto vrijeme poboljšava njegov život i smanjuje njegov defekt lošega vida. Drugi primjer jesu protetički udovi kojima se koristimo još od davnih vremena kada su se izrađivali samo od drva, dok se danas izrađuju od plastičnih materijala, drva i metala. Klasična proteza zamjenjuje ud koji čovjeku nedostaje i tako mu omogućava lakše funkcioniranje u svakodnevnom životu. Možemo spomenuti i slušni aparat koji, zapravo, uvelike pomaže čovjeku oslabljenoga sluha. Kao poveznicu između načina poboljšavanja ljudskoga života i produživanja ljudskoga života treba spomenuti razna otkrića u medicini koja su ne samo pomogla nadvladati neke čovjekove tjelesne nedostatke nego su uspjela u borbi protiv bolesti koje su redovito ljude usmrćivale u prošlim vremenima. $U$ tu kategoriju spada svakako otkriće antibiotika koje je, možemo reći, uspjelo pobijediti određene bolesti i na taj način produžiti čovjeku život. Nadalje, razni lijekovi koji pomažu kroničnim bolesnicima da održavaju svoju bolest na razini normalnoga funkcioniranja. Primjer toga jesu bolesnici s kardiovaskularnim bolestima koji su još u dvadesetom stoljeću rano umirali zbog prirode svoje bolesti, dok danas kroničnu hipertenziju ili koronarnu bolest mogu normalno održavati i živjeti s takvim bolestima. Dalje, otkrića magnetske rezonancije, ultrazvuka, rendgena, računalne tomografije doprinijela su ranijem i bržem otkrivanju bolesti, češće malignih, a posljedično i bržoj reakciji liječenja kojom bi se izliječila bolest ili barem produžio život oboljelih. Isto

${ }^{21}$ ISTI, The world factbook archives: Benin za 2000., 2007. Dostupno na: https://www.cia.gov/library/publications/download/download-2000/index.html (23. 2. 2019.). 
tako otkriće kemoterapije i radioterapije svakako je doprinijelo produžetku života ljudi oboljelih od malignih bolesti. Nadalje, bolesnicima u trajnim vegetativnim stanjima, bolesnicima u terminalnim fazama bolesti i drugim umirućim pacijentima danas je više dostupna nego prije medicinska skrb do zadnje minute života. $\mathrm{Za}$ održavanje života, često i uzaludno, upotrebljavaju se mehanička ventilacija, parenteralna prehrana, infuzije i dr. Dostupan je i širok spektar lijekova protiv bolova koji zasigurno produžuju život i smanjuju bol i patnju. Uz sav taj znanstveno-tehničko-medicinski razvitak, važno je spomenuti i općenitu promjenu svijesti ljudi, pa tako i medicine, o kraju života i borbi s bolestima, što se nekako možda može i smatrati posljedicom napretka jer medicina obećava i pruža sve više. Za medicinu je smrt pacijenta postao krajnji neuspjeh i često čini sve kako bi ju izbjegla ili barem odgodila. »Smrt, ali i njezina prethodnica umiranje, sve više poprimaju obilježja tehničke danosti, u smislu pitanja o tehničkim mogućnostima ovladavanja tim činjenicama. $\ll^{22} \gg$ Medicina borbe $\ll$, kako ju naziva dr. Laurent Alexandre u svojoj knjizi La mort de la mort, » mogla bi nas dovesti do toga da naše suočavanje sa smrću postane enigma $\ll^{23}$. Upravo ta problematika otvara govor o distanaziji koju su, zapravo, i omogućili tehnološki razvoj i razna medicinska dostignuća.

\subsection{IZAZOV DISTANAZIJE}

Sve prisutniji fenomen $\mathrm{s}$ kojim se suočava današnja medicina, koji predstavlja borbu između dobrobiti i agonije samoga pacijenta. »Borba sa životom i smrću predstavlja najveći medicinski, ali i bioetički izazov, posebice u današnje doba koje bilježi porast neizlječivih i kroničnih bolesti. One nas suočavaju s nepodnošljivim gubitcima postupnih propadanja, koje bismo najradije pokušali staviti pod medicinski nadzor i tehnološku kontrolu. $\ll^{24}$ Upravo znanstveno-tehnološki razvoj donio je mogućnost korištenja visokom medicinskom tehnologijom koja uspijeva kontrolirati čovjekov život u svim njegovim fazama, pa čak i onoj završnoj. Utjecaj medicinskih dostignuća na ljudski život promijenio je čovjekovo poimanje smrti. Dok se nekada smrt prihvaćala kao normalan i neizbježan dio života, danas bi ju čovjek najradije htio izbjeći. »Ovakvom su ishodu pogodovali različiti čimbenici, a na poseban način racionalistički scijentizam koji je nastojao znanstvenom svemoći potisnuti činjenicu životne ograničenosti i konačnosti, biomedicinskim tehnološ-

${ }^{22}$ T. MATULIĆ, Bioetičko tematiziranje ljudskog umiranja: umiranje u procjepu medicinskog tehnicizma i ontoantropološkog »personizma«, u: Crkva u svijetu 40(2005.) 1, 29-62., ovdje 30.

${ }^{23}$ L. ALEXANDRE, La mort de la mort: Comment la technomédecine va bouleverser l'humanité, Pariz, 2001., 36.

${ }^{24}$ S. VULETIĆ, Biomedicinski i moralno-etički aspekti distanazije. U agoniji umiranja pred medicinskom beskorisnošću, u: Diacovensia 22(2014.)2, 163-200., ovdje 164. 
kim dostignućima. ${ }^{25}$ Zbog toga čovjek čini sve kako bi produžio život za dan, sat, mjesec ili godinu te istodobno barem malo odgodio nastupanje smrti. To se postiže korištenjem različitim medicinskim postupcima radi liječenja, ali i održavanja pacijenta na životu. Onda kada ne postoji nada za izlječenje, a bez obzira na to nastavlja se koristiti medicinskim i terapijskim sredstvima, može se govoriti o terapijskoj upornosti, terapijskom nasilju, odnosno medicinskoj beskorisnosti ili distanaziji ${ }^{26}$.

Riječ distanazija vuče korijene iz grčkoga jezika i kovanica je od dviju riječi $d y s$ ('čin s grješkom') i thanatos ('smrt'), što u prijevodu znači 'otežana smrt, smrt sa zaprjekom. ${ }^{27}$ Ona označava $\gg$ medicinsko ponašanje koje se sastoji u korištenju terapijskih postupaka čiji efekt je škodljiviji od štetnih učinaka kojega treba liječiti, ili beskoristan, jer je liječenje nemoguće i očekivana pogodnost je manja od predvidivih neprilika $\ll^{28}$. Drugim riječima, odnosi se na liječenje koje ne daje pozitivne rezultate, a time se produžava agonija, umiranje i svakako pojačava patnja i samoga pacijenta i njegove obitelji. Uzevši u obzir patnju koja se povećava i produžuje, može se reći da se u cjelokupnom procesu distanazije zapravo zanemaruje kvaliteta života pacijenta i njegovo dostojanstvo, a u središte stavlja produženje i održavanje života pod svaku cijenu. Može se reći da se korištenjem svim mogućim medicinskim postupcima i sredstavima u završnoj fazi života, zapravo, taj život želi spasiti, ali ublažavanje patnje kao cilj medicinske prakse sigurno se ne ostvaruje distanazijom.

Distanazija se najčešće u praksi tiče nekoliko skupina pacijenata. To su terminalni bolesnici, bolesnici u trajnom vegetativnom stanju i vitalno ugrožena novorođenčad. Za bolje razumijevanje koncepta distanazije treba iz kliničke perspektive navesti primjere načina i sredstava kojima se distanazija provodi. To mogu biti umjetno hranjenje pomoću nazogastrične sonde, mehanička ventilacija, bubrežna dijaliza, kemoterapija, primjena antibiotika, umjetna hidracija, reanimacija itd. Važno je napomenuti kako ti postupci sami po sebi nisu upitni, ali postaju upitni kada je riječ o

${ }^{25}$ Isto, 167.

${ }^{26}$ Da bi se moglo govoriti o distanaziji i njezinim implikacijama, važno je spomenuti i objasniti dva pojma koja se također odnose na smrt i umiranje. Eutanazija, koja je u medijskom prostoru općepoznata, iako se vrši rjeđe od same distanazije, definira se kao »umjetno izazivanje 'blage smrti' kod neizlječivih bolesnika, tj. namjerno skraćivanje života da bi se bolesniku skratile patnje « (A. FRKOVIĆ, Bioetički ogledi o kvaliteti života. Pitanje distanazije i eutanazije, u: Socijalna ekologija 16(2007.)2-3, 215-229., ovdje 223.). S druge strane kao točka između dviju krajnosti: eutanazije i distanazije, ortotanazija kao dostojanstvena smrt, smrt bez nepotrebnoga kraćenja i bez dodatnih patnji, tj. smrt u svoje pravo vrijeme jest smrt kakvoj treba težiti u medicini (usp. L. PESSINI, Distanazija: Do kada produžavati život?, 24.). Za osiguravanje takve smrti brine se palijativna skrb.

${ }^{27}$ Usp. S. VULETIĆ, Biomedicinski i moralno-etički aspekti distanazije, 170.

${ }^{28}$ L. PESSINI, Distanazija: Do kada produžavati život?, 25. 
pacijentu kojem ti postupci ne poboljšavaju stanje, nego samo produžavaju život $i$ ne daju nikakvu nadu za poboljšanje, već produžuju umiranje i patnju.

\subsection{PARTIKULARNi KRITERIJI ZA ODREĐIVANJE MEDICINSKE BESKORISNOSTI}

Kako se koncept distanazije ne tiče samo liječnika koji ukida određeni tretman ili ga propisuje nego i pacijenta i njegove obitelji, potrebno je odrediti medicinske, ali i pravne smjernice i kriterije za određivanje medicinske beskorisnosti. Bioetičar Edmund Pelegrino predlaže tri kriterija koji se vežu uz medicinski pogled na distanaziju, a trebaju se uzeti u obzir kod određivanja medicinske beskorisnosti: efikasnost/korisnost, zatim pogodnost i tegobnost. ${ }^{29}$ Efikasnost se odnosi na terapijsku intervenciju, odnosno doprinosi li ona boljitku pacijenta i djeluje li pozitivno na njegovo stanje. Pogodnost uključuje pacijentovo subjektivno mišljenje donosi li mu intervencija nadu u izlječenje. Ako donosi, postupak se može smatrati pogodnim. Tegobnost se odnosi na »fizičku, emocionalnu, ekonomsku ili društvenu cijenu nametnutu pacijentu postupkom $\ll^{30}$. Ako ta tri elementa pokazuju dobrobit pacijenta, onda se postupak smatra moralno opravdanim. Postoje i drugi čimbenici koji se moraju uzeti u obzir kad se određuje je li postupak beskoristan. $U$ to spadaju: vjerojatnost hoće li rezultat biti uspješan; očekivano trajanje života pacijenta u odnosu na bolest, svakako, kvaliteta života; volja pacijenta, tegobnost za ostale (troškovi i izgubljene prilike za liječenje drugih pacijenata), moralne i druge vrijednosti kao što su religijske. ${ }^{31}$ No postoje i neke situacije kada se, bez obzira na to što je postupak beskoristan, moralno opravdava njegovo provođenje. Jedna od takvih je, navodi Vuletić ${ }^{32}$, kada korištenje takvim postupkom pridonosi tomu da se obitelj uspije oprostiti i rastati s članom koji umire ili ako pak doprinosi dostojanstvenoj i bezbolnijoj smrti.

$\mathrm{Na}$ pravnoj razini također su doneseni neki kriteriji za definiranje beskorisnosti tretmana. U članku 4., stavku 3. Kodeksa medicinske etike i deontologije stoji sljedeće: »Nastavljanje intenzivnog liječenja pacijenta u ireverzibilnom terminalnom stanju medicinski nije utemeljeno i isključuje pravo umirućeg bolesnika na dostojanstvenu smrt. $\ll^{33} \mathrm{O}$ tome govore i dokumenti kao što je Preporuka 1418 Zaštita

\footnotetext{
${ }^{29}$ Usp. S. VULETIĆ, Biomedicinski i moralno-etički aspekti distanazije, 187.

${ }^{30}$ Isto, 188.

${ }^{31}$ Usp. C. L. SPRUNG i dr., Consensus Statement on the Triage of Critically Ill Patients, u: JAMA 271(1994.)15, 1200-1203., ovdje 1201.

${ }^{32}$ S. VULETIĆ, Biomedicinski i moralno-etički aspekti distanazije, 187.

${ }^{33}$ HRVATSKA LIJEČNIČKA KOMORA, Kodeks medicinske etike i deontologije. Dostupno na: https://www.hlk.hr/kodeks-medicinske-etike-i-deontologije.aspx (15. 6. 2019.).
} 
ljudskih prava i dostojanstva smrtno bolesnih i umirućih (1999.) Vijeća Europe. Na tu tematiku osvrnula se i Europska konvencija za zaštitu ljudskih prava i dostojanstva ljudskog bića u odnosu na primjenu biologije i medicine, zatim Preporuka Rec (2003.) 24 Povjerenstva ministara Vijeća Europe državama članicama o organizaciji palijativne skrbi i dr.

Dok će neki dostojanstvenu smrt htjeti pružiti u obliku eutanazije, drugi će ostvarivanje dostojanstvene smrti pronaći u pružanju palijativne skrbi umirućim pacijentima, a treći će smatrati kako smrt kao takva nikako ne može biti dostojanstvena zbog toga što ona sama po sebi ugrožava ljudsko dostojanstvo i predstavlja izvore problema i poniženja samoga čovjeka. Zbog toga žele i zahtijevaju produženje života na sve moguće načine, uz sva moguća sredstva. Danas se susrećemo s takvim stavom i željom za produženjem života u filozofskom pravcu zvanom transhumanizam.

\section{Transhumanizam kao čežnja za produženim životom}

Da produženje života nije dio znanstvene fantastike te da ideje o idealnom čovjeku koji ubija svaki dio svoje vulnerabilnosti nisu samo puki strahovi običnoga smrtnoga čovjeka pokazuje sve veći razvitak novih filozofskih pravaca i pokreta koji čovjeku pokušavaju dati novi smisao, nove zadaće i nove ciljeve. Progresivni znanstvenotehnički razvoj, a tako i razvoj medicine uvelike je utjecao i utječe na čovjekov život. Dvadeseto stoljeće razvilo je mnoge nove tehnologije koje pokušavaju, ali i uspijevaju poboljšati kvalitetu čovjekova života. Upravo tomu teži transhumanizam $\gg$ koji predstavlja novi filozofski pravac koji želi koristiti tehnologiju (neurotehnologije, biotehnologije i nanotehnologije) smatrajući kako će oni omogućiti prevladavanje ljudskih fizičkih i mentalnih 'ograničenja', te pronaći rješenje unaprjeđenja fizičkih, psiholoških i intelektualnih sposobnosti ljudskih bića $\ll^{34}$. Tu nije riječ samo o poboljšanju kvalitete ljudskoga života, već govor o transhumanizmu podrazumijeva govor o poboljšanju i unaprjeđenju samoga čovjeka.

Transhumanizam kao pokret javlja se u drugoj polovici dvadesetoga stoljeća, u doba značajnoga znanstveno-tehničkoga napretka. Kako sam naziv u sebi sadrži pojam humanizam, treba se nakratko zaustaviti i polazeći od humanizma doći do transhumanizma. Humanizam se definira kao »književni, duhovni, politički i filozofijsko-antropologijski pokret, koji je začeo talijanski pjesnik i filozof Francesco

${ }^{34}$ S. VULETIĆ, Ž. FILAJDIĆ, M. IVANČIČEVIĆ, Transhumanistička eugenika: protetička kiborgizacija ljudskog poboljšanja nanomedicinskim zahvatima, u: M. STEINER, I. ŠESTAK (ur.), Aktualne moralne teme, Međunarodni znanstveni simpozij uz 90. obljetnicu života p. Ivana Fučeka S. J. 4. prosinca 2015., Zagreb, 2016., 249. 
Petrarca u 14. stoljeću $\ll^{35}$. Prema humanizmu, čovjek može postići ispunjen život posredstvom znanja, kulture, razuma, slobode i etike. Zapravo, u središtu humanističke filozofije nalazi se čovjek kojega se promatra kroz sve dimenzije njegova života, ne zanemarujući duhovnu. Transhumanizam kao novi humanizam ne niječe humanizam, ali nudi nova sredstva za napredak i razvoj. Zapravo, i sam naziv govori o tome jer prefiks trans ${ }^{-36}$ znači 's onu stranu, preko, nad humanizmom. Dok humanizam kao sredstva za razvoj čovjeka uzima znanje, kulturu, slobodu i etiku, transhumanizam nudi sve znanstveno-tehničke alate.

Iako se pojam transhumanizma prvi puta spominje 1957. godine (Julian Huxley), suvremeno značenje dobiva osamdesetih godina kada se skupina znanstvenika počinje organizirati. Max More, jedan od predstavnika transhumanističkoga pokreta, 1988. godine objavio je prvi broj časopisa Extropy Magazine te je 1992. godine osnovao Extropy institut. ${ }^{37}$ Nick Bostrom, istaknuti predstavnik transhumanističkoga pokreta, 1998. godine zajedno s Davidom Pearceom osniva Svjetsku transhumanističku udrugu (koja danas nosi naziv Humanity+). Bostrom u svom djelu, koje je objavila Svjetska transhumanistička udruga, The Transhumanist FAQ opisuje transhumanizam dvjema definicijama. Transhumanizam definira kao $\gg$ intelektualni i kulturni pokret koji afirmira mogućnost i želju za fundamentalnim napretkom ljudskog stanja primjenom razuma, posebice razvijanjem i širenjem dostupnosti tehnologija za suzbijanje starenja i unaprjeđenje ljudskih intelektualnih, fizičkih i psihičkih kapaciteta $\ll^{38}$. No transhumanizam također promatra i kroz drugu stranu medalje. Bostrom kaže da transhumanizam otkriva problematiku i potencijalne opasnosti tehnologija koje će nam omogućiti da nadiđemo fundamentalne ljudske granice te kroz prizmu etike proučava značenje tih tehnologija. ${ }^{39}$

Transhumanizam zapravo polazi od postavke da današnji čovjek još uvijek nije ispunio sve svoje kapacitete i postigao vrhunac evolucije, odnosno razvoja. Kako bi se čovjek nastavio razvijati i iskorištavati vlastite (moguće) kapacitete, razvijaju se nove tehnologije koje u sklopu znanstveno-tehnološkoga razvoja pružaju ljudima mogućnost da se čovjeka postavi na mjesto Stvoritelja. Samim time izlazi se iz ljudske naravi i želi se proizvesti čovjek veći od čovjeka, što vodi do razine stvaranja nove vrste ljudi. Čovjek kao takav po sebi je ranjiv, vulnerabilan. Anićev Veliki

\footnotetext{
${ }^{35}$ F. ZENKO, Perspektive kršćanskog humanizma? u: Nova prisutnost 5(2007.) 1, 39-49., ovdje 41.

${ }^{36}$ Trans-, tra-, u: V. ANIĆ, Veliki rječnik hrvatskoga jezika, Zagreb, 2006., 1610.

${ }^{37}$ Usp. I. GREGURIC, Kibernetička bića u doba znanstvenog humanizma: prolegomena za kiborgoetiku, Zagreb, 2018., 75.

${ }^{38}$ HUMANITY+, The transhumanist FAQ (Frequently Asked Questions), 2003., 4. Dostupno na: https://nickbostrom.com/views/transhumanist.pdf (20. 5. 2019.).

${ }^{39}$ Isto.
} 
rječnik hrvatskoga jezika vulnerabilnost ${ }^{40}$ povezuje s krhkošću, ranjivošću, povrjedivošću, ozljedivošću, neotpornošću. U kontekstu čovjeka to bi značilo da je on podložan raznim bolovima, nezadovoljstvima, ograničenjima, trpljenju, bolestima i na kraju smrti. Što to znači za transhumanizam? Sve aspekte čovjekove ranjivosti, bilo one fizičke (bolesti, smrt) ili psihološke, intelektualne i mentalne, transhumanizam promatra kroz prizmu izvora poniženja i problema za samoga čovjeka. Zbog toga su ujedno i preprjeke za razvoj i ostvarivanje prethodno spomenutih ljudskih kapaciteta koji još nisu do kraja razvijeni. Upravo radi nadvladavanja čovjekove ranjivosti, tj. ograničenosti, čovjekova »glavna zadaća i svojevrsna moralna obveza je, smatraju posthumanisti, da nadiđe sam sebe; a to može i treba učiniti kroz nova znanstvena i tehnička dostignuća ${ }^{41}$. Nove konvergentne tehnologije (NBIC - nanotehnologija, biotehnologija, informatičke i kognitivne znanosti) razvijaju se i upotrebljavaju upravo s tim ciljem.

\subsection{IDEJA POBOLJŠANJA ČOVJEKA}

Pojam human enhancement, tj. poboljšanje čovjeka glavni je pojam koji određuje cijeli transhumanistički pokret. Podrazumijeva četiri kategorije: fizičko, kognitivno i emocionalno poboljšanje te produženje životnoga vijeka. Autori kao što su Julian Savulescu ${ }^{42}$, Anders Sandberg ${ }^{43}$ i Guy Kahane ${ }^{44}$ u tom kontekstu, osim prethodnih vrsta poboljšanja, spominju i moralno poboljšanje. Ivana Greguric navodi da osim poboljšanja transhumanizam nudi postupke nadomještanja, normalizacije i preoblikovanja čovjeka. ${ }^{45}$

Fizičko poboljšanje podrazumijeva »korištenje raznih biomedicinskih sredstava u svrhu nadilaženja tjelesnih ograničenja $\ll^{46}$, a uključuje razne proteze, umjetne organe, čipove, implantate kao što su magneti, magnetske slušalice za poboljšanje sluha, tehnike za poboljšanje vida i orijentacije itd. Izdvaja se, svakako, čip za praćenje

${ }^{40}$ Vulnerabilnost, u: V. ANIĆ, Veliki rječnik hrvatskoga jezika, 1767.

${ }^{41}$ D. GRDEN, O izazovima transhumanizma, posthumanizma i novih tehnologija. Zajednički zaštititi ljudsko, u: Glas Koncila (2019.)8, 11.

${ }^{42}$ Usp. J. SAVULESCU, B. FODDY, Le tour and failure of zero tolerance: time to relaxe doping controls, u: J. SAVULESCU, R. ter MEULEN, G. KAHANE (ur.), Enhancing human capacities, Chichester, 2011., 304-312.

${ }^{43}$ Usp. A. SANDBERG, Congnition enhancement: upgrading the brain, u: J. SAVULESCU, R. ter MEULEN, G. KAHANE (ur.), Enhancing human capacities, 71-91.

${ }^{44}$ Usp. G. KAHANE, Reasons to feel, reasons to take pills, u: SAVULESCU, R. ter MEULEN, ISTI (ur.), Enhancing human capacities, 166-178.

${ }^{45}$ Usp. I. GREGURIC, Kibernetička bića u doba znanstvenog humanizma, 92-94.

${ }^{46}$ M. SELAK, Ljudska priroda i nova epoha, Zagreb, 2013., 78. 
tjelesnih funkcija koji bi tako što je implantiran u čovjeka mjerio vitalne funkcije i doprinio očuvanju zdravlja ljudi, ali i promjenama u samom radu medicinskih djelatnika, posebice medicinskih sestara. Kroz kognitivno, tj. mentalno poboljšanje, navodi Greguric, omogućilo bi se proširenje mentalnih mogućnosti pamćenja, poboljšanja percepcije, inteligencije uz pomoć genske intervencije, neurofarmakologije ili kibernetičkih usadaka itd. ${ }^{47} \mathrm{uz}$ npr. memorijski čip, manipulaciju neuronima ili pak duboku stimulaciju mozga. Emocionalno poboljšanje, odnosno poboljšanje raspoloženja uključuje korištenje različitim uređajima kao što je Thync koji posredstvom mobilne aplikacije funkcionira na način da korisnik sam određuje u kojem se trenutku želi osjećati opušteno, a u kojem ushićeno. ${ }^{48}$ Četvrti aspekt poboljšanja odnosi se na produženje životnoga vijeka, a podrazumijeva sva sredstva i načine za postizanje besmrtnosti. Ivana Greguric u tu kategoriju svrstava kiborški digitalni um, kiborško digitalno tijelo te krioničko očuvanje tijela kojim se tijela preminulih čuvaju u tekućem dušiku kako bi u budućnosti mogla oživjeti. Vjeruju da će u budućnosti medicina moći pružiti ono što danas ne može, pa smrzavanjem tijela pokušavaju sačuvati tijelo za budućnost. Danas postoje i specijalizirane tvrtke za krioniku, od kojih je najpoznatija Alcor čiji je predsjednik transhumanist Max More.

\subsection{OD PRODULJENJA ŽIVOTNOGA VIJEKA DO BESMRTNOSTI}

Treba istaknuti da korijeni transhumanističkih misli o besmrtnosti sežu i ranije od samoga humanizma. Naime povijesnim temeljem može se smatrati Ep o Gilgamešu koji datira iz 2. tisućljeća prije Krista, a potječe iz Mezopotamije. Gilgameš, vladar grada Uruka, za svoga pomoćnika i prijatelja ima Enkiduu koji spletom okolnosti obolijeva i umire. Gilgameš, stavljen pred granice vlastite sposobnosti i moći, pogođen smrću Enkidua, odlazi u potragu za postizanjem besmrtnosti. Od tuda zapravo polaze transhumanističke ideje nudeći nadilaženje ljudskih ograničenja kao što su bolesti i smrt, ali isto tako povećavanje ljudskih sposobnosti i kapaciteta u vidu poboljšanja na svim razinama. Također sama ideja besmrtnosti čovjeka proizlazi iz toga epa.

S jedne strane za cilj je postavljeno produljenje životnoga vijeka, koje se od prošloga stoljeća uvelike i događa, što pokazuju i spomenuti statistički podatci. No u raspravi o produljenju životnoga vijeka bitno je postaviti granicu između liječenja koje može biti poboljšanje i poboljšanja koje izlazi izvan okvira sposobnosti naše ljudske vrste, kakvu transhumanizam ne promiče, nego čak konfuzno poistovjećuje u obliku nedefiniranoga poboljšanja. Transhumanist Aubrey de Grey istražuje područje starenja i smatra kako se može utjecati na sam proces starenja. Važnost

\footnotetext{
${ }^{47}$ Usp. I. GREGURIC, Kibernetička bića u doba znanstvenog humanizma, 95., 131.

${ }^{48}$ Isto, 140.
} 
toga objašnjava činjenicom da 100000 ljudi svakodnevno umire od bolesti koje su uzrokovane starenjem, ali se rješavanje toga problema ne postavlja kao prioritet. Zbog toga se starenje ne može shvaćati kao normalan dio života i treba učiniti sve kako bi se starenje kao proces izbjeglo i zapravo produžio životni vijek. Tome pomaže nanotehnologija koja primjenom nanorobota na staničnoj razini popravlja i obnavlja. Također nanotehnologijom može se stvoriti ili popraviti oštećeno tkivo. Dakle jednom u budućnosti ne će više biti potrebe za transplantacijom.

Danas su znanosti poznati uzroci starenja i propadanja stanica. »Broj koliko se puta neka stanica može podijeliti ograničen je telomerima na kraju kromosoma. $\ll{ }^{49} \mathrm{To}$ je uzrok konačnoga zaustavljanja dijeljenja stanica. Što je telomer kraći, a skraćuje se starenjem, to je sposobnost stanice da se dijeli manja. No ono što znanstvenike potiče na istraživanje načina kako zaustaviti propadanje stanica jest činjenica da se neke stanice, kao npr. embrionalne, matične i tumorske ne prestaju dijeliti, što znači da mora postojati način da se zaustavi starenje i propadanje ostalih stanica. Također postoje druge vrste koje se uspješno bore protiv svojih ograničenja i produljuju si život. Jedna od njih je Turritopsis dohrnii, tzv. besmrtna meduza. »Kada ova meduza dosegne stadij odraslih oblika i završi s razmnožavanjem, ona ne stari i ne umire, već se počne vraćati natrag u stadij mladih jedinki meduza, koje još nisu spolno sazrele. $\ll^{50}$ Upravo je to jedno od vodećih obilježja transhumanizma: produljiti životni vijek čovjeka (longevity) te ga načiniti potencijalno besmrtnim (immortality). Američki filozof Francis Fukuyama smatra da je gen za tvorbu telomeraze već kloniran te da je borba i farmaceutskih i biotehnoloških tvrtki za besmrtnost već započela. ${ }^{51}$ Drugim riječima, kako kažu transhumanisti, besmrtnost je samo pitanje vremena.

U svakom slučaju, »transhumanizam se zalaže za 'stvaranje' trans-čovjeka koji će pripremiti teren za post-čovjeka, koji će tako drastično nadići sadašnjeg čovjeka da će biti sasvim drugo biće $\ll^{52}$. Prema tomu posthumanizam označava upravo taj cilj koji transhumanizam želi postići, a to je novi čovjek, drukčiji od onoga što danas jesmo. Ovdje je zanimljivo primijetiti da se upravo između tih dvaju pojmova nailazi na apsurd. Naime transhumanizam »počiva na ekstremnom antropocentrizmu, a posthumanizam propovijeda dokidanje čovjeka kakav je do sada bio i kakav jest, njegov nestanak $\ll^{53}$. Apsurd se nalazi upravo u tome što posthumanizam čovjeka o kojem govori antropocentrizam i izdiže na pijedestal želi dokinuti, ukloniti.

\footnotetext{
${ }^{49}$ I. RUDAN, Zao zrak: Razmišljanja o zdravlju i bolesti u 21. stoljeću, Zagreb, 2018., 169.

${ }^{50}$ Isto, 192.

${ }^{51}$ Usp. F. FUKUYAMA, Kraj čovjeka?, 81.

${ }^{52}$ J. MUŽIĆ, Rat protiv čovjeka, Zagreb, 2015., 404.

${ }^{53} \mathrm{D}$. GRDEN, O izazovima transhumanizma, posthumanizma i novih tehnologija, 11.
} 


\section{Etička analiza i antropološke implikacije distanazije i transhumanizma}

Osnove profesionalne prakse medicinske djelatnosti temelje se na četirima bioetičkim načelima koja se također mogu primijeniti u skrbi za ljude u procesu umiranja. To su načelo poštovanja autonomije (poštovanje slobode i želja subjekta), načelo dobročinstva (aktivno traženje dobra subjekta), načelo neškodljivosti (nenanošenja štete pacijentu) i načelo pravednosti (podjednaka zastupljenost teškoća i dobrobiti).$^{54}$ Može li se pokušati koncept distanazije uklopiti u kontekst spomenutih načela? Uzme li se u obzir načelo autonomije, pacijent u svakom slučaju ima pravo odlučiti o tome želi li primati određeni medicinski postupak, no osobe u terminalnoj fazi bolesti često nisu u mogućnosti odlučivati te umjesto njih odlučuje obitelj i liječnik, čija će odluka možda biti u suprotnosti sa željama samoga pacijenta. Načela dobročinstva i neškodljivosti svakako se u tom slučaju krše, ali isto tako i načelo pravednosti.

Temeljno pitanje koje se tiče tematike distanazije, a odnosi se i na samu etičku prosudbu koncepta distanazije jest pitanje dostojanstva ljudske osobe. Iz kršćanskoga pogleda, dostojanstvo ljudske osobe proizlazi iz njezine stvorenosti na sliku Božju. ${ }^{55}$ Pravni će sustavi dostojanstvo promatrati kroz čovjeka kao jedinstvenu i neponovljivu individuu koja posjeduje slobodu. Često se govori o dostojanstvu ljudskoga života, kršenju dostojanstva mnogim zakonima, ljudskim pravima na dostojanstven život, ali o dostojanstvenoj smrti govori se samo u kontekstu eutanazije, i to u krivom značenju. Pobornici eutanazije smatraju kako se aktivnom eutanazijom oslobađa čovjeka boli i pridonosi dostojanstvenoj smrti. No takav je stav pomalo apsurdan zato što se ne može pridonositi dostojanstvenoj smrti tako što se namjerno usmrćuje osobu i na taj način ugrožava njezino pravo na dostojanstveno umiranje. $S$ druge strane palijativna skrb dostojanstvenoj smrti pristupa na način da pruža podršku umirućem, holističkim pristupom, ponajprije tako što odbacuje terapijski uzaludne tretmane, daje analgetike, pa i onda kada to obuhvaća skraćivanje, odnosno neprodužavanje života. ${ }^{56}$ Dostojanstveno umiranje podrazumijeva prije svega psihološku podršku umirućem $\gg$ kako ne bi ostao potpuno sam $\mathrm{i}$ kako bi shvatio da se prema njemu ophodi kao prema ljudskoj osobi do posljednjeg trenutka života $\ll^{57}$. Distanazija kao takva ne pridonosi dostojanstvenoj smrti koja je ranije opisana. Stoga je moralno nedopustiv svaki oblik terapijskoga nasilja. To

\footnotetext{
${ }^{54}$ Usp. M. ARAMINI, Uvod u bioetiku, Zagreb, 2009., 20-21.

${ }^{55}$ Usp. A. POPOVIĆ, Od slike Božje do Božjeg sinovstva. Povezanost Staroga i Novoga zavjeta na primjeru egzegetsko-teološke analize odabranih svetopisamskih tekstova, Zagreb, 2008., 51.

${ }^{56}$ Usp. M. ARAMINI, Uvod u bioetiku, 301.

${ }^{57}$ Isto.
} 
nikada ne znači i ne podrazumijeva prepuštanje osobe trpljenju, zapuštanje osobe i prekidanje skrbi i njege za pacijenta na svim razinama. ${ }^{58} \mathrm{U}$ tome se očituje poštovanje ljudske osobe, njezina dostojanstva, dostojanstva njezina života, prihvaćanje smrti kao sastavnoga dijela života, ali i pridonosi dostojanstvenoj smrti i težnji $\mathrm{k}$ ostvarivanju ortotanazije.

No, unatoč slučajevima u kojima produžavanje života završi u besmislu, za pojedine produžavanje života unedogled poprima jedini legitimni smisao života i življenja. Lapidarno rečeno, brojna obećanja o besmrtnosti koja donose transhumanisti sa sobom nose mnoga pitanja. Francis Fukuyama navodi nekoliko mogućih posljedica. ${ }^{59}$ Prema njemu, čovjek će promijeniti svoju percepciju smrti: promatrat će ju kao neko zlo koje treba izbjeći. Zatim, prihvaćanje smrti činit će se izborom luđaka, a ne nečim što treba prihvatiti kao dio ljudskosti. Na koncu, hoće li ljudi i dalje biti u stanju žrtvovati život za drugoga ili pretrpjeti žrtvu života svojih bližnjih u doba kada se život bude pred njima potencijalno protezao gotovo u beskonačnost? $\mathrm{Na}$ tom tragu, postoje i drugi ishodi koje ističe Josip Mužić. On navodi kako će uklanjanje boli i patnje donijeti sa sobom posljedice po ljudskost jer će čovjek izgubiti suosjećanje, sućut, hrabrost, junaštvo. Nadalje, prenapučenost koja bi se javila prisilila bi društva da uvedu politiku kontrole rađanja. Povezano $s$ tim, ne će zapravo biti ni potreba za rađanjem djece jer će oni već rođeni, dugovječni moći preuzeti ulogu održavanja vrste koju inače ima reprodukcija. ${ }^{60}$

Nadalje, u toj čežnji za produženjem života nameće se temeljno pitanje: Ostaje li čovjek i dalje čovjek, samo boljih sposobnosti, ili postaje nešto drugo? Uzima li si čovjek kao stvoreno, kao stvaratelj, zapravo, ulogu Stvoritelja? Tako postavljeno pitanje »ne posjeduje nužno religioznu konotaciju, već uzima u obzir činjenicu da čovjek nije sam stvorio prirodu, zbog čega ne može preuzimati prava koja pripadaju nekoj sili samostvaranja ili Tvorcu $\ll^{61}$. Prema tomu čovjek kao stvaratelj, a ne stvoritelj, ne smije si dati pravo, odnosno djelovati u smjeru poboljšanja čovjeka ako to znači nepotrebnu dugovječnost i voluntaristički i redukcionistički pogled na čovjeka, ukratko, u smjeru mijenjanja ljudskosti. To se pogotovo očituje ako se govori o ideji dugovječnosti, tj. besmrtnosti, na način da se pokušava intervenirati i mijenjati sama ljudska priroda i narav. Vezano za to, možemo se ponovno vratiti na glavna bioetička načela, no ovaj put valja dodati još i načelo vulnerabilnosti koje nalaže da se život štiti u kakvom god stanju se nalazio. Upravo to načelo pokazuje da čovjek nije sam sebi svrha i vulnerabilnost ga usmjerava prema drugomu i Drugomu.

\footnotetext{
${ }^{58}$ Isto, 302.

${ }^{59}$ Usp. F. FUKUYAMA, Kraj čovjeka?, 96.

${ }^{60}$ Usp. J. MUŽIĆ, Rat protiv čovjeka, 404.

${ }^{61}$ M. SELAK, Ljudska priroda i nova epoha, 144.
} 
Stvoren je za druge i prima život od Drugoga i od drugih. Vulnerabilnost pokazuje određeno ograničenje koje ne znači prokletstvo, već blagoslov. Cjelovit čovjek jest onaj koji zna integrirati u svojem biću iskustvo zdravlja i bolesti. Ljudskost kakvu transhumanisti žele pobijediti sastavljena je ne samo od potpunoga zdravlja nego sačinjava i ljudsku vulnerabilnost.

Ovdje se također može govoriti i o stvarnosti ljudskoga dostojanstva, koje transhumanisti žele proširiti i na posthumana bića. Dostojanstvo samo po sebi proizlazi iz same činjenice da smo ljudi, osobe i to je neotuđivo pravo, dok Nick Bostrom tvrdi da se $\gg$ dostojanstvo u modernom smislu sastoji u onome što jesmo i za što imamo potencijal postati, a ne u našem 'pedigreu' ili uzročnom podrijetlu $\ll^{62}$. Jasno je vidljivo da se takvom tezom želi svesti čovjeka na razinu bilo koje vrste (životinjske, biljne). Na djelu je određeni biocentrizam koji izjednačava vrijednost svih oblika života. No dostojanstvo čovjeka ostaje, ipak, nešto što nadilazi svaku drugu vrijednost. Pritom treba imati na umu da ni prenaglašen i isključivi antropocentrizam ne valja. U biti transhumanističke ideje o produživanju života nalazi se dakle gubitak osjećaja za čovjeka, za ono sveto u njemu i za njegovo uzvišeno dostojanstvo koje nije umanjeno ni u trenutcima bolesti, hendikepa i na kraju smrti.

\section{Umjesto zaključka: komparativna analiza}

Na temelju svega rečenoga jasno je vidljivo da je produžavanje života glavna zajednička točka i objekt promatranja distanazije i transhumanizma. Jednako je jasno kako produžetak života, kao zajednička točka, iz perspektive distanazije i transhumanizma nije shvaćen na isti način. Naime distanazijom se želi život zadržati pod svaku cijenu, uključujući zanemarivanje kvalitete života. Kako je smrtni ishod liječenja za kurativnu medicinu neuspjeh, koristit će se svakim mogućim načinom da se besmisleno pridoda vrijeme životu pacijenta. Pri tome zanemarujući njega kao osobu, njegov život i smisao takvoga života koji živi, a glavni predmet liječenja postaje njegova bolest koja je u većini situacija došla do svoga završnoga stadija.

Transhumanizmom se obećava produžetak života s eliminiranjem boli, invaliditeta i svega što je manjkavo, naglašavajući uz to i kvalitetu života. Fizičko zadovoljstvo pružit će čovjeku tijelo bez mana, veću fizičku snagu, nepodložnost bolestima, dugovječnost itd. Eliminiranje raznih psiholoških pojava u smislu depresije, ljutnje, straha, tjeskobe, uznemirenosti, zabrinutosti pružit će postčovjeku emocionalno zadovoljstvo. Sve što današnjega čovjeka čini ranjivim, transhumanizam će odbaciti te time posljedično omogućiti čovjeku tzv. bolji i kvalitetniji život. Zapravo, u sre-

${ }^{62}$ Isto, 111. 
dištu samoga transhumanizma jest promjena tradicionalnih filozofskih paradigmi života koje u svojim shvaćanjima prihvaćaju bolesti, starenje i smrt.

Iako imaju zajednički objekt promatranja, distanazija i transhumanizam imaju oprječne stavove u pojedinim pitanjima, što se može razvidno i vidjeti u djelomično komparativnoj tablici:

Tablica 1. Komparativna tablica - distanazija, transhumanizam

\begin{tabular}{|l|c|c|}
\hline & Distanazija & Transhumanizam \\
\hline Produžavanje života & + & + \\
\hline Dostojanstvo osobe & - & + - \\
\hline Ublažavanje patnje & - & + \\
\hline Smrt = neuspjeh & + & + \\
\hline Kvaliteta života & - & Eliminacija granice \\
\hline Granica & $\begin{array}{c}\text { Do koje granice } \\
\text { produžavati život? }\end{array}$ & + \\
\hline Besmrtnost & - & - \\
\hline $\begin{array}{l}\text { Beskorisnost u } \\
\text { terapijskom smislu }\end{array}$ & + & + \\
\hline Etičnost & - & + \\
\hline Holistički pristup & - & + \\
\hline
\end{tabular}

'+' označava prisutnost, uvažavanje nečega ili težnju nečemu u distanaziji/transhumanizmu

'-' označava odsutnost, zanemarivanje nečega u distanaziji/transhumanizmu 


\title{
THE CHALLENGES IN HUMAN LIFE EXTENSION BETWEEN ENHANCEMENT AND AGONY
}

\author{
Odilon-Gbènoukpo SINGBO* - Terezija GLOŽINIĆ** \\ - Anto ČARTOLOVNI***
}

Summary: The main aim of this paper is to present two different forms of human life extension. On the one hand there is dysthanasia, i.e. therapeutic persistence in the provision of life-sustaining measures to terminally ill patients, and on the other hand, transhumanism as a philosophical viewpoint which in its core strives towards unlimited extension of human life with the fundamental desire to eliminate disease, ageing and death. By putting them in correlation with the healthcare practice, the paper points to implications in clinical practice and draws attention to ethical and anthropological issues in connection with life extension.

Keywords: dysthanasia, transhumanism, medical technology, life extension, disease, death, immortality, bioethics.

* Odilon-Gbènoukpo Singbo, Ph. D., Catholic University of Croatia, Ilica 242, 10000 Zagreb, Croatia, odilonsing@gmail.com

** Terezija Gložinić, BScN, Catholic University of Croatia, Ilica 242, 10000 Zagreb, Croatia, tglozinic@unicath.hr

*** Asst. Prof. Anto Čartolovni, Ph. D., Catholic University of Croatia, Ilica 242, 10000 Zagreb, Croatia, anto.cartolovni@unicath.hr 